\title{
Treatment of the restless legs syndrome with carbamazepine: a double blind study
}

\author{
WENCHE TELSTAD, ØYVIND SøRENSEN, STIG LARSEN, PER ERIK LILLEVOLD, \\ PER STENSRUD, ROLF NYBERG-HANSEN
}

\begin{abstract}
One hundred and seventy four patients suffering from the restless legs syndrome were examined in a double blind, between patient, placebo controlled study in general practice for five weeks to investigate the effects of carbamazepine and placebo on the syndrome. The syndrome was more common among middle aged women with relatively low systolic blood pressure. The median haemoglobin concentration was about average for the population, but the severity of the symptoms seemed to increase with decreasing concentrations of haemoglobin. Both placebo and carbamazepine showed a significant therapeutic effect $(p<0.01)$. Carbamazepine was significantly more effective than placebo $(p \leqslant 0.03)$.

The significant therapeutic effect of placebo in restless legs showed that only double blind controlled trials can confirm the efficacy of suggested treatments.
\end{abstract}

\section{Introduction}

The first description of the restless legs syndrome was probably that by Willis in $1685 .^{1}$ A detailed report was given by Ekbom in $1945 .^{2}$ The syndrome constitutes an unpleasant, creeping sensation deep in the legs when they are at rest, especially in the evening and during the night. The symptoms are usually bilateral and induce an imperative need to move the legs. Pathological neurological signs are lacking. Psychological factors are of some importance, but the syndrome does not seem to be psychogenic. ${ }^{3}$

There is no known causal treatment for restless legs. We performed a placebo controlled trial to investigate the therapeutic effect of carbamazepine in the restless legs syndrome and, if possible, to characterise those who suffer from it.

\section{Patients and methods}

We carried out a multicentre trial in general practice, which was monitored by an executive committee. It was a randomised double blind, between patient trial of five weeks' duration in which apparently identical tablets of carbamazepine $100 \mathrm{mg}$ and placebo

Moa Helsehus, 6010 Spjelkavik, Norway

WENCHE TELSTAD, MD, general practitioner

4600 Kristiansand $S$, Norway

ØYVIND SØRENSEN, MD, general practitioner

Nordic Statistical Centre, Medical Department, Ciba-Geigy Pharma

A/S, 2010 Strømmen, Norway

STIG LARSEN, MSC, statistician

Medical Department, Ciba-Geigy Pharma A/S

PER ERIK LILLEVOLD, MSC, cell biologist

Department of Neurology, National Hospital, University of Oslo, Norway

PER STENSRUD, MD, assistant chief physician, neurologist

ROLF NYBERG-HANSEN, MD, professor, neurologist

Correspondence to: Dr W Telstad. were used. The starting dosage was one tablet of carbamazepine or placebo at bedtime for the first week. The daily dose could be increased by one tablet a week up to a maximum of three during the following two weeks according to the therapeutic effect or side effects, or both, and then remained unchanged for the remaining two weeks of the study. Patients who withdrew from the study for reasons unrelated to treatment were replaced by new patients similarly randomised to treatment. Patients who dropped out for reasons related to the treatment were included in the final analysis.

Altogether 181 patients were admitted to the study including seven who dropped out for reasons not related to the treatment and seven who replaced them. Thus 174 (122 women and 52 men) were included in the analysis. All patients gave their informed consent to participate. We excluded pregnant women; patients with liver, renal, or blood diseases; varices in their legs, or polyneuropathy; and patients taking drugs containing phenothiazine.

Initially, and after three and five weeks of treatment, the patients' weight, blood pressure, and heart rate were measured. Haemoglobin and serum iron concentrations were measured at the start of the trial, and the serum concentration of carbamazepine was determined after three and five weeks. No metabolites of carbamazepine were measured.

The number of attacks of the restless legs syndrome during each week of the study was recorded. The severity of the symptoms was reported by each patient at the start of the study and after three and five weeks according to a $15 \mathrm{~cm}$ visual analogue scale. ${ }^{4}$ The therapeutic effect of the drug taken was measured in the same way after three and five weeks. Unwanted effects were recorded at each visit, and their severity was indicated on a visual analogue scale of $10 \mathrm{~cm}$.

Statistical analysis-Most results are expressed as medians with 95" ${ }^{\circ}$ confidence intervals and total ranges. To construct the confidence intervals we used the Bernoulli-Wilcoxon procedure. ${ }^{5} \mathrm{All}$ tests used in this analysis were one tailed. ${ }^{6}$ Differences were considered to be significant when the $\mathrm{p}$ values were less or equal to a $5^{\prime \prime}$, level. Categorised data analyses were used to compare the frequency of the syndrome between groups ${ }^{7}$; changes in frequencies were analysed with the diagonal sign test. ${ }^{7}$ Non-parametric methods with correction for ties were used to test differences and changes in continuously distributed variables. ${ }^{5}$ Correlation analysis was carried out by Kendall's ? method. ${ }^{8}$

\section{Results}

The groups were similar with regard to sex, concomitant diseases, and treatment for ailments other than the restless legs syndrome (table I). Age, duration of disease, and baseline values of variables

TABLE I-Sex of patients and presence of concomitant disease and treatment

\begin{tabular}{|c|c|c|c|c|c|c|}
\hline \multirow{2}{*}{ Drug received } & \multicolumn{2}{|c|}{ No of patients } & \multicolumn{2}{|c|}{$\begin{array}{c}\begin{array}{c}\text { Concomitant } \\
\text { disease }\end{array} \\
\end{array}$} & \multicolumn{2}{|c|}{$\begin{array}{l}\text { Concomitant } \\
\text { treatment }\end{array}$} \\
\hline & Women & Men & Yes & No & Yes & No \\
\hline $\begin{array}{l}\text { Carbamaz } \\
\text { Placebo }\end{array}$ & $\begin{array}{l}57 \\
65\end{array}$ & $\begin{array}{l}27 \\
25\end{array}$ & $\begin{array}{l}37 \\
48\end{array}$ & $\begin{array}{l}47 \\
42\end{array}$ & $\begin{array}{l}23 \\
35\end{array}$ & $\begin{array}{l}61 \\
55\end{array}$ \\
\hline
\end{tabular}

measured were closely similar in the two groups (table II). The groups were also similar initially with regard to the number of attacks per week (table III) and the severity of symptoms (fig 1). In the third and fifth weeks of treatment a significant improvement was found in both groups $(\mathrm{p}<0.01)$, but carbamazepine was significantly more effective than placebo (table III, figs 1,2 ). The increase in therapeutic effect (fig 2) from the third to the fifth week was significant 
TABLE II-Age, duration of disease, and initial values of variables measured in patients given carbamazepine (drug) and placebo

\begin{tabular}{|c|c|c|c|c|c|c|c|c|c|c|c|c|c|c|}
\hline & \multirow{2}{*}{\multicolumn{2}{|c|}{ Age (years) }} & \multirow{2}{*}{\multicolumn{2}{|c|}{$\begin{array}{c}\text { Duration of } \\
\text { disease (years) }\end{array}$}} & \multirow{2}{*}{\multicolumn{2}{|c|}{$\begin{array}{l}\text { Haemoglobin } \\
(\mathrm{g} / \mathrm{dl})\end{array}$}} & \multicolumn{4}{|c|}{ Blood pressure $(\mathrm{mm} \mathrm{Hg})$} & \multirow{2}{*}{\multicolumn{2}{|c|}{$\begin{array}{c}\text { Heart rate } \\
\text { (beats } / \mathrm{min} \text { ) }\end{array}$}} & \multirow{2}{*}{\multicolumn{2}{|c|}{ Weight $(\mathrm{kg})$}} \\
\hline & & & & & & & \multicolumn{2}{|c|}{ Systolic } & \multicolumn{2}{|c|}{ Diastolic } & & & & \\
\hline & $\begin{array}{c}\text { Drug } \\
(n=84)\end{array}$ & $\begin{array}{l}\text { Placebo } \\
(\mathbf{n}=88)\end{array}$ & $\begin{array}{c}\text { Drug } \\
(n=83)\end{array}$ & $\begin{array}{l}\text { Placebo } \\
(n=84)\end{array}$ & $\begin{array}{c}\text { Drug } \\
(\mathrm{n}=79)\end{array}$ & $\begin{array}{l}\text { Placebo } \\
(n=83)\end{array}$ & $\begin{array}{c}\text { Drug } \\
(n=84)\end{array}$ & $\begin{array}{l}\text { Placebo } \\
(n=89)\end{array}$ & $\begin{array}{l}\text { Drug } \\
(n=84)\end{array}$ & $\begin{array}{l}\text { Placebo } \\
(n=89)\end{array}$ & $\begin{array}{c}\text { Drug } \\
(n=84)\end{array}$ & $\begin{array}{l}\text { Placebo } \\
(\mathbf{n}=87)\end{array}$ & $\underset{(n=84)}{\text { Drug }}$ & $\begin{array}{l}\text { Placebo } \\
(n=88)\end{array}$ \\
\hline \multirow{2}{*}{$\begin{array}{l}\text { Median } \\
95 \% \text { confidence } \\
\text { interval }\end{array}$} & $52 \cdot 5$ & 52 & 10 & 8 & 137 & $13 \cdot 8$ & 130 & 130 & 80 & 80 & 72 & 72 & 64.5 & 66.0 \\
\hline & $49 \cdot 5-57 \cdot 5$ & $48 \cdot 3-55 \cdot 0$ & $8-15$ & $5-10$ & $13 \cdot 2-14 \cdot 1$ & $13 \cdot 5-14 \cdot 3$ & $120-139$ & $124-140$ & $80-85$ & $80-85$ & $70-72$ & $72-76$ & $62-70$ & $61-68$ \\
\hline Total range & $25-86$ & $17-79$ & $13 \cdot 2-14 \cdot 1$ & $13 \cdot 5-14 \cdot 3$ & $10 \cdot 5-16 \cdot 8$ & $11 \cdot 8-16 \cdot 7$ & $85-190$ & $95-190$ & $60-105$ & $60-100$ & $52-90$ & $52-96$ & $40-101$ & 44-114 \\
\hline
\end{tabular}

TABLE III-Frequency of attacks experienced by patients receiving carbamazepine (drug) and placebo

\begin{tabular}{|c|c|c|c|c|c|c|}
\hline \multirow{2}{*}{$\begin{array}{c}\text { No of } \\
\text { attacks/week }\end{array}$} & \multicolumn{2}{|c|}{ Initially } & \multicolumn{2}{|c|}{ Week 3} & \multicolumn{2}{|c|}{ Week 5} \\
\hline & Drug & Placebo & Drug & Placebo & Drug & Placebo \\
\hline 0 & & & 28 & 22 & 41 & 24 \\
\hline 1 & 1 & 2 & 15 & 7 & 10 & 12 \\
\hline 2 & 10 & 9 & 10 & 10 & 6 & 14 \\
\hline 3 & 12 & 12 & 5 & 14 & 8 & $\begin{array}{r}14 \\
7\end{array}$ \\
\hline 4 & 14 & 9 & 8 & 3 & 6 & 8 \\
\hline 5 & 10 & 9 & 4 & 5 & 3 & 1 \\
\hline 6 & 6 & 7 & i & 5 & 0 & 4 \\
\hline 7 & 31 & 42 & 13 & 23 & 10 & 19 \\
\hline p & \multicolumn{2}{|c|}{ NS } & \multicolumn{2}{|c|}{$p=0.04$} & \multicolumn{2}{|c|}{$p=0.03$} \\
\hline
\end{tabular}

in the group receiving carbamazepine $(p=0.02)$ but not in the group receiving placebo ( $p-0 \cdot 07)$.

The median daily doses taken in weeks four and five were carbamazepine $236 \mathrm{mg}$ and placebo $257 \mathrm{mg}$. The median serum concentration of carbamazepine after five weeks of treatment was $283 \mu \mathrm{g}$ $100 \mathrm{ml}(12 \mu \mathrm{mol} / \mathrm{l})$ (range $23 \cdot 6-637 \mu \mathrm{g} / 100 \mathrm{ml}(1-27 \mu \mathrm{mol} / \mathrm{l})$ ).

Thirty four patients in the group receiving carbamazepine (including six withdrawals) and 20 in the placebo group (including two withdrawals) experienced unwanted effects, but no serious side effects were observed.

During the five weeks of the study the systolic blood pressure decreased significantly $(p-0.02)$ in both groups from a median of 130 to $125 \mathrm{~mm} \mathrm{Hg}$.

\section{Discussion}

Both carbamazepine and placebo had a significant effect on restless legs. Carbamazepine was significantly more effective than placebo, but the placebo effect was remarkable. In view of this many drugs that have been recommended in this syndrome, such as vasodilators, ${ }^{3}$ analgesics, ${ }^{3}$ sedatives, ${ }^{3}$ hypnotics, ${ }^{3}$ iron, ${ }^{9}$ and antiepileptics, ${ }^{10} "$ may have been considered to be of therapeutic value because of a placebo effect. To the best of

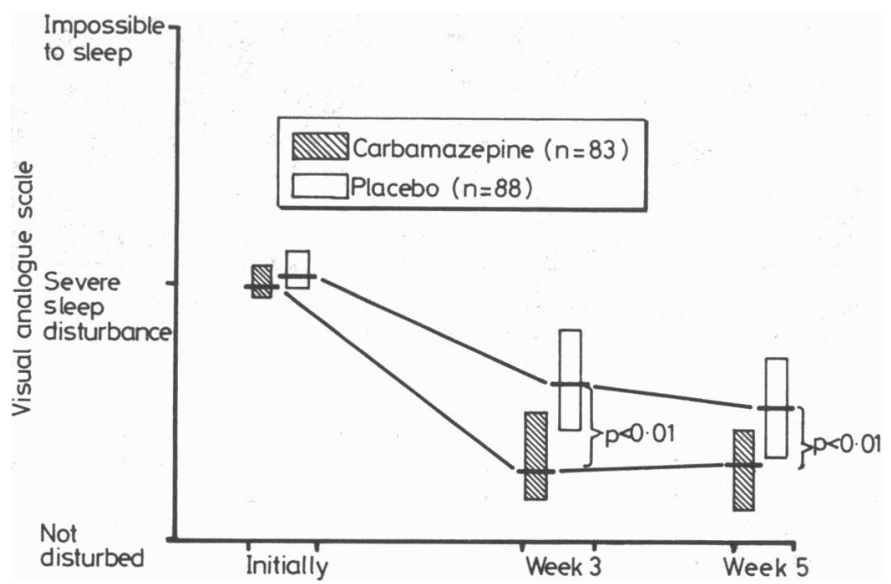

FIG 1-Severity of symptoms of the restless legs syndrome as indicated by patients on visual analogue scale. Columns indicate $95 \%$ confidence intervals horizontal lines crossing columns indicate median values.

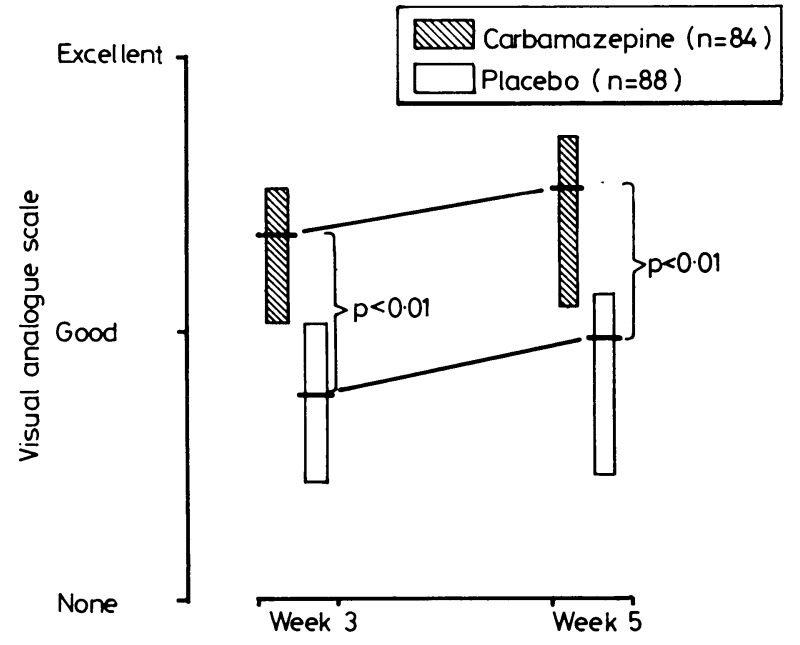

FIG 2-Therapeutic effect of drugs as judged by patients on visual analogue scale. Columns indicate $95 \%$ confidence intervals; horizontal lines crossing columns indicate median values.

our knowledge placebo controlled trials to verify their therapeutic efficacy have never been performed. Carbamazepine may have been ineffective in some patients because we used a lower dose of the drug than that used in epilepsy. ${ }^{12}$ This suggestion is supported by the positive correlation between the reduction in the severity of symptoms and the serum concentration of carbamazepine $(r=0 \cdot 26)$.

Ekbom ${ }^{2}{ }^{3}$ and Selvaag ${ }^{13}$ found an equal sex distribution among their patients. In our study, however, roughly $70 \%$ of the patients were women. Ekbom found no preponderance of the disease in any particular age group, ${ }^{3}$ whereas Selvaag found a higher prevalence among middle aged people, ${ }^{13}$ as did we in our patients.

The median haemoglobin concentration does not indicate that the restless legs syndrome is caused by anaemia. The negative correlation between haemoglobin concentration and the initial severity of symptoms $(r=-0.37)$, however, indicates that anaemic patients experience more severe symptoms. This may explain why iron treatment has been successful in some cases. $^{3}$ The large range of serum iron concentrations $(<3-$ $65 \mu \mathrm{mol} / 1(<17-363 \mu \mathrm{g} / 100 \mathrm{ml})$, which probably occurred because our blood sampling procedure was not adequately standardised, makes it impossible to suggest any connection between this variable and restless legs.

At the start of treatment the patients' median blood pressure was $130 / 80 \mathrm{~mm} \mathrm{Hg}$ and median age 52 years. The mean blood pressure in the Norwegian population of corresponding age is at least $145 / 80 \mathrm{~mm} \mathrm{Hg}$ in women and $142 / 82 \mathrm{~mm} \mathrm{Hg}$ in men. ${ }^{14}{ }^{15}$ Only two patients received antihypertensive treatment. This suggests that the restless legs syndrome is more common among middle aged women with relatively low systolic blood pressure.

Finally, the significant therapeutic effect of the placebo implies that double blind clinical trials are the only way to verify the efficacy of suggested treatments for restless legs. Such a trial is now in progress. 

Epilepsy, Sandvika, and his staff for their excellent laboratory work, and gratefully acknowledge the skilful data handling by $\mathrm{Mr}$ Gorm Jenseg and the secretarial work of Ms Brit Aastorp.

\section{References}

${ }^{1}$ Willis T. The London practice of physick. London: Thomas Basset and William Crook, 1685.

${ }^{2}$ Ekbom KA. Restless legs. Acta Med Scand 1945;158, suppl:1-123.

3 Ekbom KA. Restless legs syndrome. Neurology 1960;10:68-73.

4 Osnes M, Larsen S, Eidsaunet W, Thom E. Effect of diclofenac and naproxen on gastroduodenal mucosa. Clin Pharmacol Ther 1979;26: 399-405.

${ }^{5}$ Lehmann EL, D'Abrera HJM. Non-parametrics: statistical methods based on ranks. San Francisco: Holden-Day, 1975.

${ }^{6}$ Sverdrup E. Significance testing in multiple statistical inference. Scandinavian fournal of Statistics $1976 ; 3: 73-8$.
We thank Dr Svein I Johannessen of the National Centre for
' Kendall M, Stuart A. The advanced theory of statistics. Vol 2. London: Charles Griffin, 1979.

${ }^{8}$ Kendall M. Rank correlation methods. London: Charles Griffin, 1975.

${ }^{9}$ Ekbom KA. Restless legs. In: Vinken PJ, Bruyn GW, eds. Handbook of clinical neurology. Amsterdam: New Holland, 1970:311-20.

${ }^{10}$ Read DJ, Feest TG, Nassim MA. Clonazepam: effective treatment for restless legs syndrome in uraemia. $\mathrm{Br} \mathrm{Med} \mathcal{F} 1981 ; 283: 885-6$.

11 Matthews WB. Treatment of restless legs syndrome with clonazepam. Br Med F 1979;i:751.

12 Johannessen SI. Antiepileptic drugs: pharmacokinetic and clinical aspects. Ther Drug Monit 1981 ;3:17-37.

${ }^{13}$ Selvaag O. Restless legs. In: Medicinsk Årbok. Copenhagen: Munksgaard,

14 Humerfelt SB. An epidemiological study of high blood pressure. Acta Med Scand 1963;175, suppl 407:1-233.

${ }^{15}$ Bjartveit K, Foss OP, Gjervig T. The cardiovascular disease study in Norwegian counties. Results from first screening. Acta Med Scand 1983;214, suppl 675:1-184. 1961-2:407-17.

(Accepted 10 November 1983)

\section{SHORT REPORTS}

\section{Traumatic brain stem haematoma without prolonged loss of consciousness}

Injuries to the brain stem are generally part of severe, diffuse damage to the brain. Patients with such damage rarely do well and are nearly always comatose from the initial impact until death. We report a case of brain stem haematoma that resolved.

\section{Case report}

An 18 year old man presented to the casualty department after an object had fallen on his head. He regained consciousness before admission, which was within two hours after the injury. Neurological examination yielded normal findings, and plain $x$ ray examination of his skull showed no fracture. He was therefore discharged home. He returned in two days complaining of generalised headaches, constant vertigo, and difficulty in sitting up together with inability to walk because of lack of balance.

On examination he was alert and the optic discs were normal. He had internuclear ophthalmoplegia with normal convergence. His pupils reacted normally. There was no other abnormality in the cranial nerves. Limb coordination was appreciably impaired bilaterally with truncal ataxia. Power and tone were normal. Tendon reflexes were generally sluggish with bilateral equivocal plantar responses. No sensory abnormality was detected.

Computed tomography of the head showed a small area of high density in the midline of the upper brain stem, with no blood in the ventricles, normal cisterns, and no sign of diffuse injury to the white matter. Repeated computed tomography after two and four weeks showed gradual and complete resolution of the haematoma (figure). Examination of cerebrospinal fluid five days after the incident showed no xanthochromia; biochemical values, cell count, and IgG fraction were normal. Brain stem auditory and visual evoked responses one week after the accident were normal. Results of vertebral angiography with subtraction views carried out at the end of the fifth week were normal with no features suggesting arteriovenous malformation.

His condition improved considerably with conservative management. The internuclear ophthalmoplegia and ataxia resolved, and no residual symptoms or signs were present on discharge. A year later he was still well.

\section{Comment}

Brain stem lesions in closed head injury indicate diffuse brain damage and a grave prognosis. ${ }^{1-3}$ Crompton reported 106 cases seen at necropsy and stated that brain stem lesions were common in patients surviving initial head injury in prolonged $\mathrm{coma}^{1}$; Adams et al concluded that diffuse damage to white matter is the pathological basis of primary "brain stem injury" because in none of their patients were the abnormalities confined to the brain stem. ${ }^{3}$ Neither of these, however, seems to be the case in our patient as he was fully alert throughout and his original loss of consciousness lasted less than two

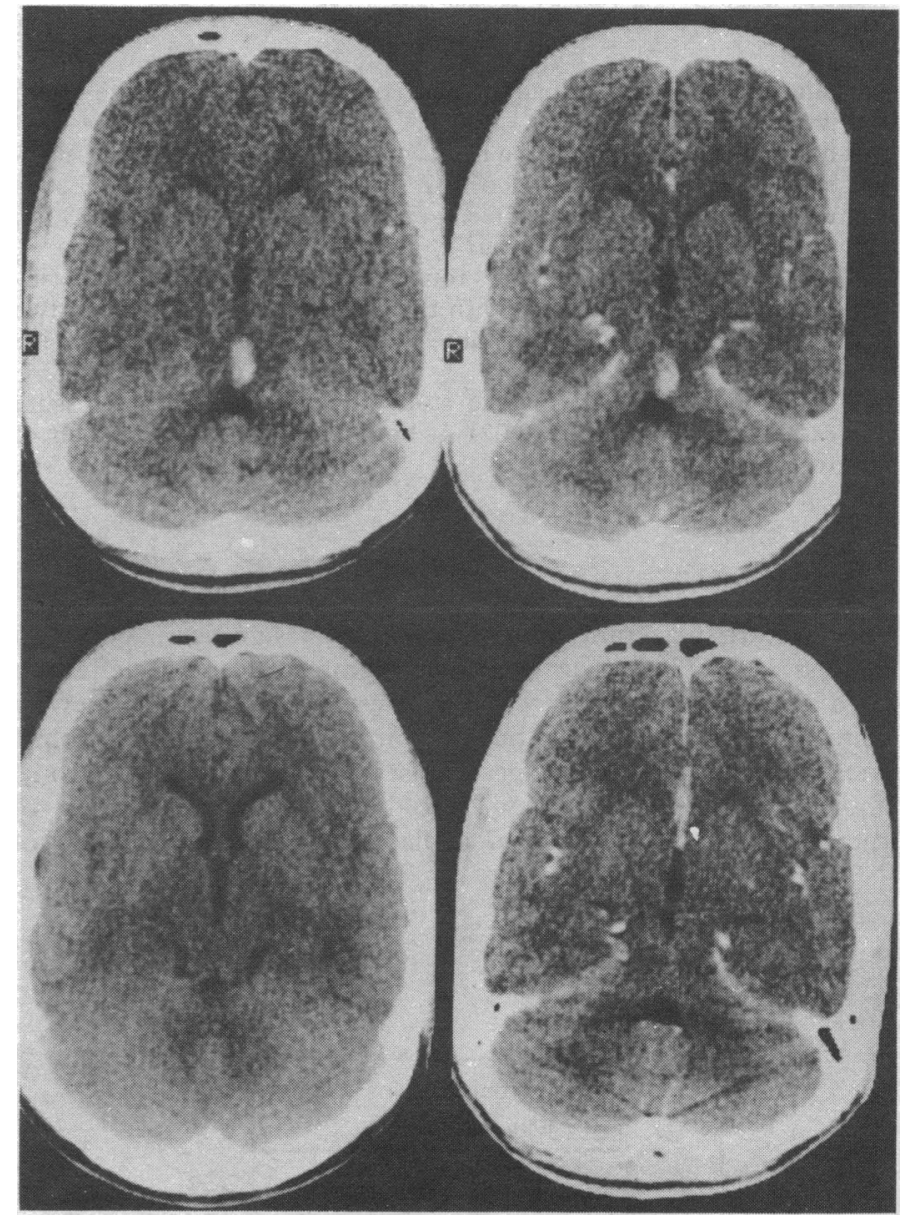

Computed tomograms before (left) and after (right) contrast, showing brain stem haematoma (top) and total resolution four weeks later (bottom).

hours. The internuclear ophthalmoplegia indicates that the lesion was in the upper pons; it was in the midline and probably interrupted the cerebellar pathways, leading to the main presenting symptom, gross ataxia. His clinical state and the absence of cerebral contusion, oedema, and ventricular haemorrhage in the computed tomograms rule out the possibility of diffuse damage to the white matter.

The normal vertebral arteriogram and the cerebrospinal fluid findings render bleeding due to an aneurysm or an arteriovenous malformation unlikely. Central brain stem haematomas after head 